\section{Developmental Morphology of Switchgrass and Sideoats Grama ${ }^{1}$}

\author{
PHILLIP L. SIMS, LUCAS J. AYUKO'2, \\ AND D. N. HYDER
}

Assistant Professor and Graduate Student, Department of Range Science, Colorado State University; and Range Scientist, Crops Research Division, Agricultural Research Service, U. S. Department of Agriculture, Fort Collins, Colorado.

\section{Highlight}

A study was made of the vegetative expansion, floral development, and responses to mowing of switchgrass and sideoats grama. Vegetative expansion in switchgrass was primarily by rhizomes, proaxis buds, and continuation of arrested growth, in that order. Vegetative expansion in sideoats grama was mainly by proaxis buds and the continuation of arrested growth, in that order. Mowing at about 3 $\mathrm{cm}$ aboveground decreased herbage production, stopped reproductive shoots after inflorescence elevation, and initiated tillering from rhizomes and proaxes of both species, and decreased the length of the third and fourth internodes of sideoats grama.

Two important characteristics of a grass plant are growth-rhythm and response to utilization. The rhythm of growth begins with the emergence of aerial shoots in early spring. During the growing season physiological processes in some shoots initiate the development of reproductive parts. Both

${ }^{1}$ Cooperative investigations of the Crops Research Division, Agricultural Research Service, U. S. Department of Agriculture, and the Colorado Agricultural Experiment Station, Fort Collins, Colorado. Published with the approval of the Director of the Colorado State University Experiment Station as Scientific Series Paper No. 1549. The study is part of Colorado's contribution to Great Plains Project 9, Growth and Development of Selected Range Grasses as Related to Grazing on the Great Plains. Received September 3, 1970; accepted for publication December I, 1970.

2 Present address is Range Management Division, Ministry of Agriculture, Box 30028, Nairobi, Kenya ( $\Lambda$ frica). vegetative and reproductive shoots mature toward the end of the growth season and either die or go dormant to start growth the following year. The rhythm of growth is characterized by a sequential development of leaves during the vegetative phase, and later by maturation of reproductive organs.

Response to utilization is a behavioral characteristic of a grass that is important in grazing management. Grass leaves removed by grazing animals are replaced by new leaves from the growing points, or from tillers when the growing points are removed.

The purpose of this investigation was to study the developmental morphology of switchgrass (Panicum virgatum (L.) var. Caddo) and sideoats grama (Bouteloua curtipendula (Michx.) Torr. var. El Reno). Knowledge of the development from the start of growth to floral differentiation, and from floral differentiation to dormancy of these grasses, is basic to the understanding of their growthrhythm and response to utilization.

\section{Methods and Procedures}

The study area was at the Eastern Colorado Range Station near Akron, Colorado. The average annual precipitation is 38 centimeters ( 15 inches). About 75 percent falls as rain during the period from April 1 to August 31. The average frost free period is about 140 days (from mid-May to early October). The soil on the study site is a Blakeland loamy sand and has a dark surface of more than 6 inches. This soil often grades into a noncalcareous sand with no restrictive layers within $150 \mathrm{~cm}$ of the surface.

Plant material was collected from 2-year old, pure, seeded stands of the two improved grass varieties. Four randomly selected clumps of each species were collected on April 11, May 1, and then weekly until August 25, 1967. The soil was excavated from around the clumps, and the sod was carefully lifted out of the ground so as not to destroy the proaxis portion of the shoots. After removal of the soil from the plant material, each clump was placed in a plastic bag and frozen for observation at a later time.

The phytomer is the unit of growth derived from a single leaf primordium and includes the blade, sheath, internode, 


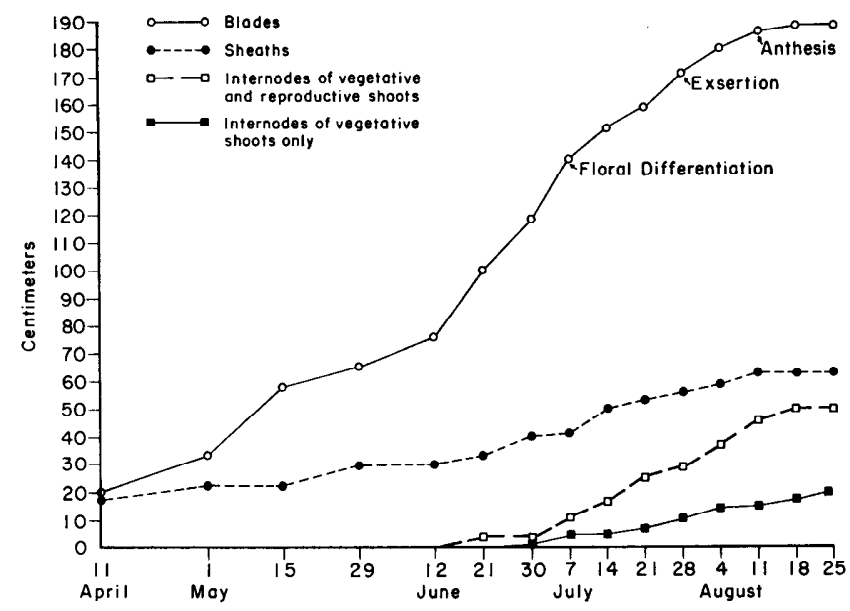

Fig. 1. Lengths per shoot of blades, sheaths, and internodes of Caddo switchgrass on various sampling dates. The exserted parts were not measured separately.

axillary bud or meristamatic potential, and node (Evans and Grover, 1940; Gray, 1879; Weatherwax, 1923). Beginning with the first (lower most) phytomer, each blade, sheath, and internode was measured separately. After a blade, sheath, and internode had been measured and the length recorded, the blade and sheath were carefully removed by using a teaser needle to expose the next phytomer according to the procedure of Sharman (1947). This operation was continued until the smaller and more delicate blades and sheaths were measured. The exserted portions of leaves were not measured separately. Rather, the total length of blades and sheaths, whether exserted or enclosed in older sheaths, were recorded. The internodes were measured individually when they were over 1 millimeter long or collectively when they were less than a millimeter long. The average lengths of these phytomer parts were used to construct growth curves for each phytomer.

The locations of the aerial shoots were noted to determine if the phytomers originated from axillary buds of the proaxis, the stem, rhizome, or from terminal rhizomes. In midOctober, when the heads of reproductive shoots had exserted, several clones were selected at random, excavated, and broken apart to permit a count of the number of reproductive and vegetative shoots.

To study the effects of mowing switchgrass and sideoats grama at different growth stages, 11 plots, $.76 \mathrm{M}$ by $5.5 \mathrm{M}$, were staked out across a strip of each species. Beginning May 29, a new plot was mown, at a height of $3 \mathrm{~cm}$, each week with a rotary mower for 11 consecutive cutting times. On August 16 and October 14 two to three clones wcre collected from each plot, and the general pattern of the development of axillary buds of the crown and the rhizomes was observed. Comparative observations were made of mown and unmown plants. Stems were examined for any sign of increased axillary bud activity, changes in internode elongation, and increase or decreases in tillering as a result of mowing. Another observation determined the time at which the inflorescences were removed by mowing.

\section{Results}

Growth Curves

The growth curves of Caddo switchgrass shoots are shown in Figure 1. Blade elongation was con-
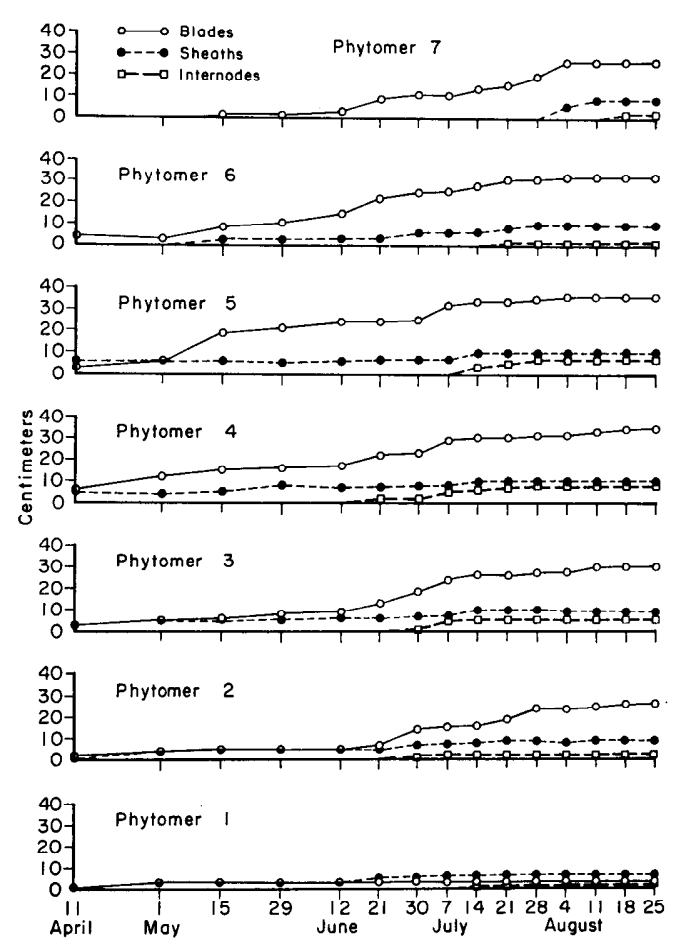

Fig. 2. Average lengths of individual phytomer parts of Caddo switchgrass. The exserted parts were not measured separately.

sistent throughout the season and the most rapid growth occurred just before and upon floral differentiation. Sheath elongation followed the same general pattern as blade elongation but was less marked, especially during the early part of the season.

Extensive internode elongation commenced after spikelet-bud differentiation, and the rudimentary inflorescences of switchgrass were not elevated above the ground surface until mid-June. In contrast, Branson (1953) found that the growing points of switchgrass were elevated above the ground earlier in the season. Two weeks after floral differentiation, the culms of vegetative shoots began to elongate, and they attained an average maximum length of $18 \mathrm{~cm}$ by August 18 .

Figure 2 presents the growth curves of the average lengths of the parts of individual phytomers of Caddo switchgrass. The total number of leaves on reproductive shoots ranged from six to nine, mostly six. The blades evinced a slow-rapid-slow growth pattern but the sheaths were gradual in growth. The average lengths of successive internodes increased from the first to the fifth, then the lengths decreased from the fifth to the seventh.

Blade elongation of El Reno sideoats grama was comparatively slow at the beginning of the season (Fig. 3). Rapid blade elongation occurred from May 15 until after head exsertion. Sheath elongation was gradual in sideoats grama. Rapid internode elongation of reproductive shoots of El Reno sideoats grama occurred between mid-July and the 


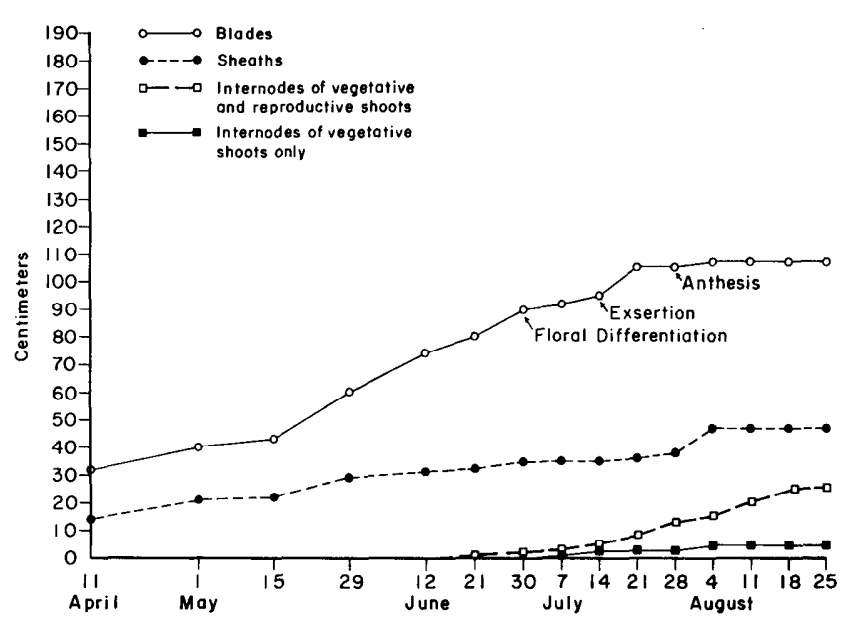

FIc. 3. Lengths per shoot of blades, sheaths, and internodes, of EI Reno sideoats grama on various sampling dates. The cxserted parts were not measured separately.

latter part of August. The growing points of the vegetative shoots of sideoats grama remained at about $3 \mathrm{~cm}$ above the ground after being slightly elevated shortly after floral differentiation.

The growth curves of the individual phytomers of sideoats grama are shown in Figure 4. The total number of leaves on reproductive shoots varied from six to seven, mostly six. Blades of the second, third, and fourth phytomers exhibited the typical sigmoid curve growth pattern. No individual sheath showed any definite rapid growth at any time during the season. Internode elongation was progressive from the first to the top.

\section{Vegetative Expansion and Floral Development}

The main pattern of vegetative expansion by Caddo switchgrass was by rhizomes, axillary buds of the proaxis, and continuation of arrested vegetative growth, in that order. El Reno sideoats grama expanded from axillary buds of the proaxis and the shoot apices of arrested vegetative shoots, in that order. The rhizomcs of sidcoats grama, which were not as numerous or as long as in switchgrass, did not contribute significantly to the production of new shoots. In both species reproductive shoots produced most of the rhizomes, and vegetative shoots produced most of the tillers.

Floral differentiation of both switchgrass and sideoats grama took place in late June. Head exsertion occurred in the second week of July for sideoats grama and in the third week of July for switchgrass. Anthesis was in the fourth week of July for sideoats grama and in the first week of August for switchgrass.

\section{Reproductive to Vegetative Shoot Ratio}

In mid-October switchgrass had a ratio of one reproductive to 3.8 vegetative shoots. This ratio is low compared with that of 2.15 reproductive to
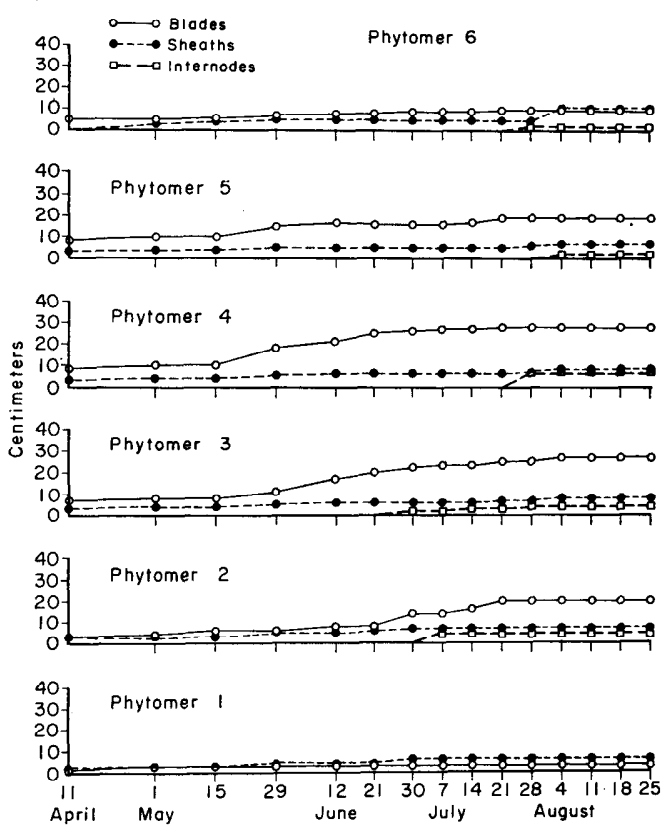

Fig. 4. Average lengths of individual phytomer parts of E1 Reno sideoats grama. The exserted parts were not measured separately.

one vegetative reported by Branson (1953). The switchgrass plants examined in this study had a high proportion of small tillers which lowered the percentage of reproductive shoots. Sideoats grama had approximately one reproductive to 2.2 vegetative shoots. This compared favorably with Branson's (1953) ratio of 0.48 reproductive to one vegetative shoot.

\section{Effects of Mowing}

Mowing switchgrass and sideoats grama in early spring did not seem to affect seedhead production, but mowing toward the end of spring season progressively reduced the number of seedheads. Switchgrass plants in mown plots produced seedheads up to June 19 mowing, then progressively fewer reproductive shoots were produced on successively later mowing dates. No mown plants produced seedheads after June 26. By mid-June the inflorescences were just elevating aboveground, but by June 26 they were about $4 \mathrm{~cm}$ aboveground (Fig. 1). Mowing on June 26 removed these inflorescences and stopped shoot growth. This stoppage of reproductive shoots stimulated the growth of new tillers from axillary buds.

Some sideoats grama plants produced seedheads after the June 26 mowing because some inflorescences were still below cutting height. By July 3, the reproductive shoots had inflorescences aboveground. All of these inflorescences were removed by mowing resulting in no seedhead production after this date. Laude (1957) found that the removal of the entire inflorescence of soft chess (Bromus mollis L.) resulted in the growth cessation 
of that shoot, but if a portion of the inflorescence was retained the shoot continued to grow.

The rhizomes of mown plants of sideoats grama and switchgrass, instead of remaining underground to start new growth the following season, immediately turned upward and produced aerial shoots. These shoots grew and produced seedheads, if the plants were mown before June 26 (switchgrass) and July 3 (sideoats grama). The rhizomes of switchgrass plants mown after June 26 , and sideoats grama plants mown after July 3, turned upward and produced small leaves and then went dormant. Mowing after these critical dates did not seem to activate rhizome growth. When a plant was mown, not only the rhizomes produced aerial shoots, but the proaxis buds of both sideoats grama and switchgrass also produced shoots. Mowing resulted in more tillers from the rhizomes and proaxes of sideoats grama than of switchgrass.

All of the sideoats grama plants mown between June 19 and July 3 exhibited a much-reduced elongation of the third and fourth internodes. The average length of the second, third, fourth, and fifth internodes of unmown plants was 12, 32, 40, and $19 \mathrm{~mm}$, respectively. The second, third, fourth, and fifth internodes of mown sideoats grama plants were $14,4,5$, and $18 \mathrm{~mm}$ respectively. This relationship held true for all collection dates that were examined, June 19, July 3, and August 4.

\section{Literature Cited}

Branson, Farrel A. 1953. Two new factors affecting resistance of grasses to grazing. J. Range Manage. 6:165171.

Evans, Morgan W., and F. O. Grover. 1910. The developmental morphology of the growing point of the shoot and the inflorescence of grasses. J. Agr. Res. 61:481-520.

GraY, A. 1879. Structural botany. American Book Company, New York. $112 \mathrm{p}$.

Laude, Horton M. 1957. Growth of the annual grass plant in response to herbage removal. J. Range Manage. 10:37-38.

Sharman, B. C. 1947. The biology and developmental morphology of the shoot apex in the Gramineae. New Phytol. 46:20-34.

Weatherwax, Paul. 1923. The story of the maize plant. Illus. Univ. Chicago Press, Chicago. 247 p. 